\title{
Evaluation of upper endoscopic findings in patients with restless legs syndrome and gastric complaints
}

\author{
Avaliação dos achados endoscópicos superiores em pacientes com síndrome das pernas \\ inquietas e queixas gástricas
}

Mustafa CAM', Ufuk KUTLUANA²

\begin{abstract}
Background: The effect of gastrointestinal system disorders on Restless Legs Syndrome/Willis-Ekbom disease (RLS/WED) has been previously demonstrated by using serological tests. However, this association has not been supported by histopathological studies so far. Objective: To investigate the relationship between RLS/WED, upper endoscopic imaging and histopathological results in patients diagnosed with RLS who underwent endoscopy because of gastrointestinal system (GIS) complaints. Methods: Case-control study, including 100 patients diagnosed with RLS who presented dyspeptic complaints and underwent upper GIS endoscopy and 106 age- and sex-matched controls. RLS diagnosis was evaluated according to the four main diagnostic criteria determined by the International RLS Study Group. All patients underwent upper GIS endoscopic intervention and at least one gastric and/or antral biopsy. Results: There was no significant difference between patients and controls in relation to endoscopically seen gastric ulcer, duodenal ulcer, gastroesophageal reflux disease (GERD) findings and Helicobacter pylori (HP) positivity ( $p>0.05$ ). Intestinal metaplasia and mucosal atrophy were more common in RLS/WED patients compared to controls $(p=0.026$ and $p=0.017$, respectively). Additionally, ferritin levels were found to be lower than the reference value. Conclusions: The detection of increased severity of intestinal metaplasia, mucosal atrophy, and gastric inflammation in RLS/WED patients with dyspeptic complaints may entail the close gastrointestinal system evaluation of these patients. However, larger randomized and controlled trials are required on this subject where patients are evaluated by upper GIS endoscopic biopsy.
\end{abstract}

Keywords: ferritin; Helicobacter pylori; RLS; sleep disorder; atrophic gastritis; intestinal metaplasia; endoscopy.

RESUMO

Introdução: Os efeitos das doenças do sistema digestório sobre a Síndrome das Pernas Inquietas/doença de Willis-Ekbom (SPI/DWE) foram demonstrados previamente por testes sorológicos. No entanto, até o momento tal associação não foi corroborada por estudos histopatológicos. Objetivo: Investigar a relação entre a SPI/DWE, imagens de endoscopia digestiva alta e resultados histopatológicos em pacientes diagnosticados com SPI/DWE com queixas do sistema digestório. Métodos: Estudo caso-controle incluindo 100 pacientes com SPI/DWE e queixas dispépticas que foram submetidos à endoscopia digestiva alta, e 106 controles emparelhados para idade e sexo. O diagnóstico de SPI/DWE foi determinado com base nos quatro principais critérios do International RLS Study Group. Todos os pacientes foram submetidos à intervenção endoscópica do sistema digestório superior e a pelo menos uma biópsia gástrica e/ou antral. Resultados: Não houve diferença significativa entre os grupos em relação à úlcera gástrica endoscopicamente observada, úlcera duodenal, doença do refluxo gastroesofágico (DRGE) e positividade para Helicobacter pylori (HP) ( $p>0,05)$. Metaplasia intestinal e atrofia da mucosa foram mais comuns em pacientes com SPI/DWE em comparação aos controles ( $p=0,026$ e $p=0,017$, respectivamente). Niveis de ferritina encontravam-se abaixo do valor de referência. Conclusão: A detecção de metaplasia intestinal grave, atrofia de mucosa e inflamação gástrica em pacientes com SPI/DWE com queixas dispépticas pode justificar a avaliação cuidadosa do sistema digestório nestes pacientes. Entretanto, são necessários estudos controlados e com amostras maiores com pacientes avaliados com biópsia por via endoscópica.

Palavras-chave: ferritina; Helicobacter pylori; distúrbio do sono; gastrite atrófica; metaplasia intestinal; endoscopia.

${ }^{1}$ Canakkale Onsekiz Mart University, School of Medicine, Department of Neurology, Canakkale, Turkey.

${ }^{2} U$ șak Univerrity School of Medicine, Department of Internal Medicine, Ușak, Turkey.

Mustafa ÇAM (iD https://orcid.org/0000-0003-3116-203X; Ufuk KUTLUANA iD https://orcid.org/0000-0002-2323-5756

Correspondence: Mustafa Çam; Department of Neurology; Çanakkale Onsekiz Mart University Çanakkale 17000, Turkey; E-mail: mustafacam20@hotmail.com Conflict of interest: There is no conflict of interest to declare.

Received on May 16, 2019; Received in its final form on October 19, 2019; Accepted on November 10, 2019. 
Restless Legs Syndrome/Willis-Ekbom disease (RLS/WED) is a disease that obviously and suddenly occurs in the legs and arms. It is difficult to identify and is characterized by a disturbing sensation and relaxation with movement ${ }^{1,2}$. There is an irresistible need for movement associated to an abnormal sensation in the legs, which is difficult to describe. The symptoms that can be prominent particularly at night compared to daytime usually occur in immobile position. RLS/WED is considered a common disease, with mild symptoms seen in 5 - $15 \%$ of the general population ${ }^{3-5}$.

The exact cause of RLS/WED remains unknown. However, there are idiopathic and secondary forms of RLS/WED associated with various medical conditions, such as anemia, pregnancy, uremia, neuropathies, rheumatoid arthritis and neurological disorders ${ }^{6}$. Current evidence for the pathophysiology of RLS/WED suggests that the dopaminergic dysfunction and the central nervous system (CNS) alter the control of iron homeostasis with a subsequent disruption in iron distribution $^{7}$. In previous studies, it has been considered that the identification of the pathophysiological process of RLS/WED development in patients with gastrointestinal (GIS) problems may enable additional therapeutic options for patients diagnosed with RLS/WED.

The aim of this study was to evaluate the relation between RLS/WED and upper endoscopic imaging and histopathological results in patients with RLS/WED who underwent endoscopy because of GIS complaints.

\section{METHODS}

\section{Patients}

This cross-sectional and case-control study was conducted in the Gastroenterology Clinic of Denizli State Hospital between January and August 2018. The study included 100 patients diagnosed with RLS/WED who presented at our clinic with dyspeptic complaints and underwent upper GIS endoscopy, and 106 age- and sex-matched controls. Written consent was obtained from each participant included in the study after obtaining the approval by the Local Ethics Committee for the study. The clinical, laboratory, endoscopic and histopathological findings of all participants were evaluated in combination.

\section{Inclusion and exclusion criteria}

The patients included in the study were aged $>18$ years, with diagnosis of RLS/WED and had complaints concerning their digestive system. The control group was composed by age- and sex-matched subjects with only dyspeptic complaints and no diagnosis of RLS/WED. Patients were excluded from the study if they had a history of known neurological disease (such as Parkinson's disease, multiple sclerosis, radiculopathy), drug use affecting dopamine levels and activity, sleep disorder, rheumatic disease (rheumatoid arthritis, scleroderma, systemic lupus erythematosus, known peptic ulcer, chronic renal failure, thyroid disease, anemia, chronic liver disease, antibiotic use in the last six months, or severe gastritis symptoms).

\section{Neurological examination and description of RLS/WED}

A detailed neurological examination was performed by the neurologist in all cases. Deep tendon reflexes, pathological reflexes, muscle strength, touch, joint position, and extrapyramidal findings were evaluated. The RLS/WED diagnosis was evaluated according to the four main diagnostic criteria, determined by the International RLS Study Group ${ }^{2,8}$. The criteria are:

- A sudden movement of the legs, often in a restless and disturbing manner.

- The occurrence of an uneasy and sudden feeling when sitting and while resting or lying in bed.

- A decrease or complete disappearance of the feeling of discomfort when walking or during stretching exercises.

- $\quad$ Restless and sudden movements more frequent and more serious at night than during the day.

In this process, we identified the following six primary non-RLS conditions, whose symptoms mimic those of RLS leading subjects to subscribe to all four diagnostic criteria defining RLS. We asked additional questions to differentiate these mimics from RLS (leg cramps, peripheral neuropathy, radiculopathy, arthritic pains, positional discomfort and pronounced or frequent unconscious foot or leg movements) ${ }^{8}$.

All subjects diagnosed as RLS/WED positive were asked to complete the 10-item International Restless Legs Syndrome Rating Scale (IRLSRS) to evaluate the severity of their symptoms.

\section{Laboratory tests}

At the same day of the clinical evaluation, blood samples were obtained from all participants at 9 a.m. after overnight fasting, using aseptic venipuncture. All samples were processed in the laboratories of the Clinical Microbiology Department of Denizli State Hospital. Full blood count, erythrocyte sedimentation rate, blood iron levels (ferritin and transferrin saturation), vitamin B12 levels, liver, kidney and thyroid function tests were measured with routine laboratory methods in the sera of all patients.

\section{Upper GIS endoscopy}

Endoscopic procedures were performed in the left lateral position in all patients to prevent aspiration and hypotension. Patients were administered $2 \mathrm{~mL}$ of $10 \%$ lidocaine 
spray orally, 1-5 minutes before the endoscopy while they were sitting on the operating table. Cardiac rhythms and oxygen saturations $\left(\mathrm{SpO}_{2}\right)$ of all patients were monitored with close monitorization at 5-minute intervals. All procedures were performed under conscious sedation with intravenous midazolam.

At least one gastric and/or antral biopsy was performed as needed in all patients. Giemsa staining was performed for the pathological evaluation of Helicobacter pylori (HP) infection. The preparations were evaluated by a hospital pathologist who specialized in gastrointestinal (GI) pathology and had no knowledge of the study.

\section{Helicobacter pylori status}

A gastric antral mucosal biopsy was performed in all patients to determine HP status. These biopsies were tested using the rapid urease test observed for color change. In the presence of HP in the gastric material, the solution in the CLO kit was expected to change from yellow to pink. In cases where color changes were not observed immediately, the solution was re-evaluated after 24 hours. If no color changes were then observed, the test was recorded as negative, regardless of the use of PPI or eradication therapy.

\section{Statistical analysis}

Data obtained in the study were analysed statistically using SPSS 25.0 software (IBM Corporation, Armonk, New York, United States). The conformity of data to normal distribution was evaluated with the Shapiro-Wilk test. The MannWhitney U test was used with Monte Carlo results in comparison with RLS/WED and Control groups, in terms of the quantitative variables of age, vitamin B12, transferrin saturation, and ferritin. Spearman's rho test was used to examine the correlations of RLSSID variable with age, HP infection status, intestinal metaplasia, atrophy, inflammation, vitamin B12, transferrin saturation, and ferritin variables. The Pearson's chi-square test was used with the Exact and Monte Carlo simulation results in comparison with RLS/WED and Control groups, in terms of HP status, intestinal metaplasia, atrophy, and chronic gastritis variables. Fisher's Exact test was used with the exact results in comparison with the groups, in terms of gastric ulcer, and reflux disease variables. The Fisher-Freeman-Holton test was used with the Monte Carlo Simulation method to compare the groups in terms of intestinal metaplasia, atrophy, and inflammation variables, and the column ratios were compared with each other and expressed according to the Benjamini-Hochberg corrected $p$-value results. The odds ratio was used with $95 \%$ confidence intervals to show the greater likelihood of those with a risk factor compared to those without. The sensitivity and specificity rates were examined with the ROC (Receiver Operating Curve) analysis to assess the relation between the classification made with the cut-off value calculated according to the ferritin variables of RLS/WED and control groups and the actual classification. The quantitative variables were shown as mean \pm standard deviation (SD) and median (minimummaximum) values, and categorical variables were shown as number (n) and percentage (\%) in the tables. The variables were analyzed at a $95 \%$ confidence interval and $p<0.05$ was accepted as statistically significant.

\section{RESULTS}

Overall, 206 individuals were evaluated, comprising $100(48.5 \%)$ patients diagnosed with RLS/WED and 106 (51.5\%) patients with dyspeptic complaints only and no diagnosis of RLS/WED as the control group. Age and sex distributions of RLS/WED and control groups were similar, and the endoscopic imaging findings and endoscopic gastric biopsy results of all patients are shown in Table 1 . There was no significant difference between the groups in terms of endoscopically seen gastric ulcer, duodenal ulcer, gastroesophageal reflux disease (GERD) findings and HP positivity $(\mathrm{p}>0.05)$.

The findings of intestinal metaplasia and mucosal atrophy were more common in patients in the RLS/WED group compared to the control group $(\mathrm{p}=0.026$ and $\mathrm{p}=0.017$, respectively). Histopathological findings consistent with celiac disease were determined in two of the patients diagnosed with RLS/WED, whereas no such finding was observed in any of the patients in the control group (Table 1).

The mean vitamin B12 levels and transferrin saturation values of the control and RLS/WED groups were similar. The mean ferritin levels of patients in the RLS/WED group were significantly lower compared to those of the control group $(\mathrm{p}<0.001)$. When the cut-off value was taken at $17.9 \mathrm{ng} / \mathrm{mL}$, ferritin levels were determined with $70.8 \%$ sensitivity and $72.5 \%$ specificity in determining the patients with RLS/WED with a ferritin level $<17.9 \mathrm{ng} / \mathrm{mL}$ [AUC (SE): 0.724 (p=0.039), Odds Ratio: 6.4 (3.3-12.2)] (Table 1 and Figure 1).

When the RLS/WED and control groups were compared according to the severity of HP positivity and histopathological findings, severe levels of intestinal metaplasia, mucosal atrophy and inflammation were seen to be more common in the RLS/WED group than in the control group ( $\mathrm{p}=0.007$; $p=0.034$; and $p<0.001$, respectively) (Table 2). No significant difference was seen between the RLS/WED and control groups in terms of HP positivity, serum vitamin B12 level and transferrin saturation $(\mathrm{p}>0.05)$ (Table 2).

A moderate positive correlation was seen between the severity of histological inflammation and the severity of disease in patients with RLS/WED. There was a moderate negative correlation between the ferritin level and the severity of RLS/WED. No such correlation could be shown in terms 
of age, HP positivity, vitamin B12 and transferrin saturation (Table 3).

In the RLS/WED group, the level of ferritin >17.9 was found to be 5,592 [CI95\% (2.776-11.264)] times higher than in the control group $(\mathrm{p}<0.001)$. The predictive success of the model was $76.4 \%$ for the RLS/WED group, $64.8 \%$ for the control group, and $70.6 \%$ for the overall prediction success, which was statistically significant $(\mathrm{p}<0.001)$ (Table 4).

\section{DISCUSSION}

The exact pathophysiology of RLS/WED remains unclear. Most patients diagnosed with RLS/WED are considered idiopathic. However, secondary RLS/WED is seen with various underlying medical conditions, such as iron deficiency anemia, renal failure, and pregnancy ${ }^{5}$. In previous studies, it has been shown that common GI diseases, such as irritable bowel

Table 1. Demographic, endoscopic and pathological findings of the patients included in the study.

\begin{tabular}{|c|c|c|c|c|}
\hline & & $\begin{array}{c}\text { RLS/WED (+) } \\
(n=100) \\
\text { Median (Min./Max.) }\end{array}$ & $\begin{array}{l}\text { Control }(n=106) \\
\text { Median (Min./Max.) }\end{array}$ & $p$-value \\
\hline \multirow[t]{2}{*}{ Age (years) } & & $42.5(19 / 67)$ & $41(19 / 76)$ & $0.370^{\mathrm{a}}$ \\
\hline & & $n(\%)$ & $\mathrm{n}(\%)$ & \\
\hline \multirow{2}{*}{ Sex } & Male & $15(15.0)$ & $16(15.1)$ & $0.999^{b}$ \\
\hline & Female & $85(85.0)$ & $90(84.9)$ & \\
\hline \multirow{2}{*}{$\begin{array}{l}\text { Helicobacter pylori } \\
\text { (Pathology) }\end{array}$} & Negative & $31(31.0)$ & $39(36.8)$ & $0.462^{b}$ \\
\hline & Positive & $69(69.0)$ & $67(63.2)$ & \\
\hline \multirow{2}{*}{$\begin{array}{l}\text { Intestinal metaplasia } \\
\text { (Pathology) }\end{array}$} & Absent & $80(80.0)$ & $97(91.5)$ & $0.026^{b}$ \\
\hline & Present & $20(20.0)$ & $9(8.5)$ & $2.7(1.2-6.2)^{\star}$ \\
\hline \multirow{2}{*}{$\begin{array}{l}\text { Mucosal atrophy } \\
\text { (Pathology) }\end{array}$} & Absent & $85(85.0)$ & $101(95.3)$ & $0.017^{b}$ \\
\hline & Present & $15(15.0)$ & $5(4.7)$ & $3.6(1.2-10.2)^{\star}$ \\
\hline \multirow{2}{*}{ Chronic gastritis (Pathology) } & Absent & $43(43.0)$ & $35(33.0)$ & $0.153^{b}$ \\
\hline & Present & $57(57.0)$ & $71(67.0)$ & \\
\hline \multirow{2}{*}{$\begin{array}{l}\text { Duodenal ulcer } \\
\text { (Endoscopic) }\end{array}$} & No & $94(94.0)$ & $100(94.3)$ & $0.999^{b}$ \\
\hline & Yes & $6(6.0)$ & $6(5.7)$ & \\
\hline \multirow{2}{*}{ Gastric ulcer (Endoscopic) } & No & $97(97.0)$ & 104 (98.1) & $0.676^{\circ}$ \\
\hline & Yes & $3(3.0)$ & $2(1.9)$ & \\
\hline \multirow{2}{*}{ GERD (Endoscopic) } & No & $96(96.0)$ & $101(95.3)$ & $0.999^{\circ}$ \\
\hline & Yes & $4(4.0)$ & $5(4.7)$ & \\
\hline \multirow{2}{*}{ Celiac (Pathology) } & No & $98(98.0)$ & 106 (100.0) & - \\
\hline & Yes & $2(2.0)$ & $0(0.0)$ & \\
\hline \multirow{2}{*}{$\begin{array}{l}\text { Barrett Esophagus } \\
\text { (Endoscopic) }\end{array}$} & No & $99(99.0)$ & $105(99.1)$ & - \\
\hline & Yes & $1(1.0)$ & $1(0.9)$ & \\
\hline Vitamin B12 (pg/mL) & & $279(104 / 641)$ & 256 (102 / 576) & $0.770^{a}$ \\
\hline Ferritin $(\mathrm{ng} / \mathrm{mL})$ & & $10.4(1.1 / 107)$ & $24(1.3 / 127)$ & $<0.001^{a}$ \\
\hline Transferrin saturation (\%) & & $26(6 / 50)$ & $26(9 / 45)$ & $0.962^{\mathrm{a}}$ \\
\hline \multirow[t]{3}{*}{ Ferritin } & & & & $<0.001^{d}$ \\
\hline & $<17.9 \mathrm{ng} / \mathrm{mL}$ & $63(70.8)^{\text {ss }}$ & $25(27.5)$ & AUC (SE): 0.724 (0.039) \\
\hline & $>17.9 \mathrm{ng} / \mathrm{mL}$ & $27(29.2)$ & $81(72.5)^{\mathrm{sp}}$ & $6.4(3.3-12.2)^{*}$ \\
\hline
\end{tabular}

aMann-Whitney U test (Monte Carlo); bPearson chi-square test (Exact); cFisher's exact test (exact); dRoc Curve Analysis (Youden index J - Honley\&Mc Nell); *Odds Ratio (95\% confidence interval); AUC: Area under the ROC curve; ss: sensitivity; sp: specificity; SE: standard error; Min.: minimum; Max.: maximum. 


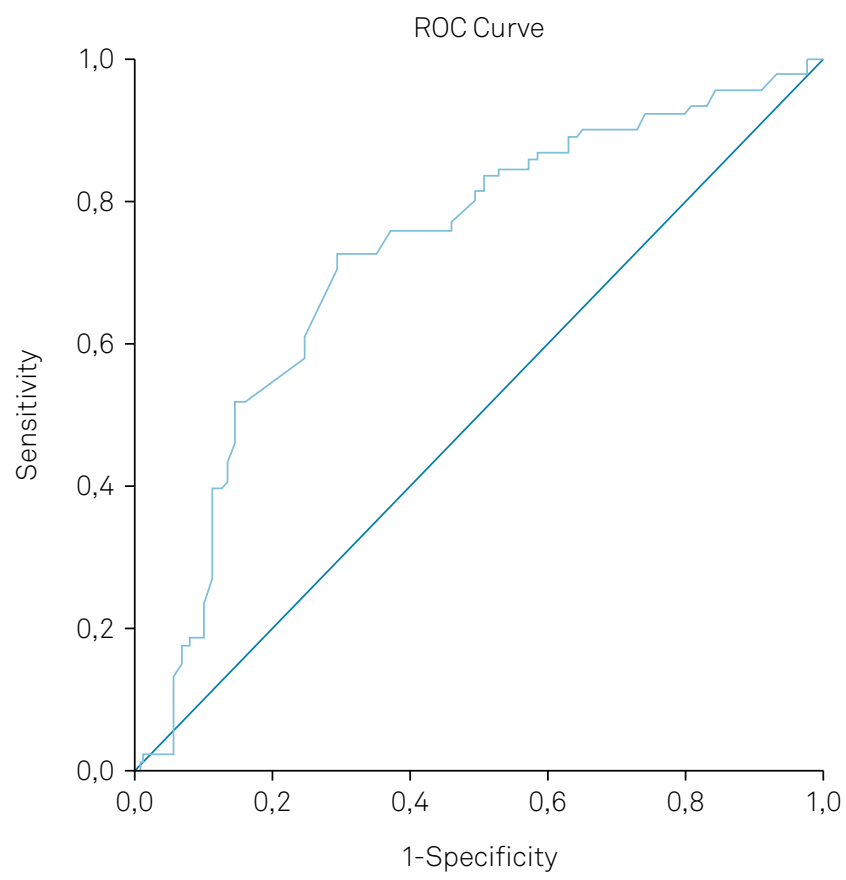

Figure 1. ROC Curve analysis for ferritin [AUC (SE): 0.724 (0.039)].

Table 2. Evaluation of the severity of pathological findings in patients.

\begin{tabular}{|c|c|c|c|c|}
\hline & & $\begin{array}{l}\text { RLS/WED } \\
(+) \text { Patients } \\
(\mathrm{n}=100) \\
n(\%)\end{array}$ & $\begin{array}{l}\text { Control } \\
\text { group } \\
(n=106) \\
n(\%)\end{array}$ & $p$-value \\
\hline \multirow{4}{*}{$\begin{array}{l}\text { Helicobacter } \\
\text { pylori } \\
\text { positivity } \\
\text { (Pathology) }\end{array}$} & 0 & $29(29.0)$ & $37(34.9)$ & $0.283^{*}$ \\
\hline & + & 18 (18.0) & 27 (25.5) & \\
\hline & +++ & $36(36.0)$ & $28(26.4)$ & \\
\hline & ++++ & $17(17.0)$ & $14(13.2)$ & \\
\hline \multirow{4}{*}{$\begin{array}{l}\text { Intestinal } \\
\text { metaplasia } \\
\text { (Pathology) }\end{array}$} & None & $80(80.0)$ & $97(91.5)^{a}$ & $0.007 * *$ \\
\hline & Mild & $2(2.0)$ & $5(4.7)$ & \\
\hline & Moderate & $11(11.0)^{b}$ & $3(2.8)$ & \\
\hline & Severe & $7(7.0)^{\mathrm{B}}$ & $1(0.9)$ & \\
\hline \multirow{4}{*}{$\begin{array}{l}\text { Mucosal } \\
\text { atrophy } \\
\text { (Pathology) }\end{array}$} & None & 85 (85.0) & $101(95.3)^{a}$ & $0.034 * *$ \\
\hline & Mild & $8(8.0)$ & $4(3.8)$ & \\
\hline & Moderate & $5(5.0)^{b}$ & $0(0.0)$ & \\
\hline & Severe & $2(2.0)$ & $1(0.9)$ & \\
\hline \multirow{4}{*}{$\begin{array}{l}\text { Inflammation } \\
\text { (Pathology) }\end{array}$} & None & $0(0.0)$ & $4(3.8)^{a}$ & $<0.001$ \\
\hline & Mild & $41(41.0)$ & $74(69.8)^{\mathrm{a}}$ & \\
\hline & Moderate & $33(33.0)^{b}$ & $18(17.0)$ & \\
\hline & Severe & $26(26.0)^{b}$ & $10(9.4)$ & \\
\hline
\end{tabular}

*Pearson chi-square test (Monte Carlo); **Fisher Freeman Halton test (Monte Carlo); Post-hoc test: Benjamini-Hochberg correction; a: significant compared to the RLS group; b: significant compared to the control group. syndrome (IBS $)^{9,10}$, Celiac $^{11}$, Crohn's $^{12}$ disease and chronic liver diseases ${ }^{13}$ were associated with a high RLS/WED prevalence. In the present study, ferritin decrease, gastric inflammation severity, mucosal atrophy, and intestinal metaplasia frequency were increased in patients with RLS/WED compared to healthy individuals.

Intestinal metaplasia may develop because of chronic atrophic gastritis and severe inflammation, which sometimes leads to irreversible mucosal destruction. As a result, the absorption of essential elements and vitamins can deteriorate significantly in the mucosal barrier with a deteriorated structure. Although this is thought to be caused by chronic inflammation, it is also thought that this is affected by the underlying autoimmune gastritis process, which is close to the pathophysiology of RLS/WED development. In a study by Appak et al. ${ }^{14}$, chronic gastritis was associated with significant decreases in the sleep and quality of life scores in children. In parallel with this, in the present study, the findings of intestinal metaplasia and mucosal atrophy were found to be more frequent in patients with RLS/WED ( $p=0.026$ and $p=0.017$, respectively). However, further studies evaluating the pathogenesis of autoimmune gastritis could provide important information.

Although it is accepted that iron deficiency anemia has an effect on the development of secondary RLS/WED, Weinstock et al. ${ }^{12}$ determined that iron deficiency present in patients diagnosed with Crohn's Disease was not associated to the frequency of RLS/WED symptoms. However, the fact that iron deficiency was significantly associated with the emergence of RLS/WED symptoms has been emphasized in other studies. Previous studies show that hepcidin expression was increased in systemic inflammatory conditions. An increase in hepcidin may lead to a decrease in iron absorption, which may impair iron distribution in the central nervous system ${ }^{15}$. Studies with adults with gastrointestinal diseases, such as peptic ulcer and gastroesophageal reflux, report lower quality of life scores compared to the normal population, and these scores have been shown to significantly increase after treatment ${ }^{16,17}$.

Table 3. Correlations of pathological evaluations of RLS/WED severity and laboratory findings.

\begin{tabular}{lcc}
\hline Severity of RLS/WED & $r$ & p-value \\
\hline Helicobacter pylori positivity & 0.085 & 0.223 \\
Severity of intestinal metaplasia & 0.165 & 0.018 \\
\hline Severity of mucosal atrophy & 0.163 & 0.019 \\
Severity of inflammation & 0.288 & $<0.001$ \\
\hline Ferritin & 0.356 & $<0.001$ \\
\hline Transferrin saturation (\%) & 0.010 & 0.890 \\
\hline
\end{tabular}

Spearman's rho Test; r: correlation coefficient. 
$\mathrm{HP}$ is a bacterium that lives in the stomach and the upper part of the duodenum and is very common in Turkey. HP infection has been associated to chronic GIS problems (IBS, dyspepsia), and rheumatic (RA, fibromyalgia, AS) and neurological diseases (Parkinson's disease, Alzheimer) ${ }^{18}$.

RLS/WED is frequently seen in patients with gastrointestinal diseases, and there are studies suggesting that this is associated to HP-related autoimmunity and iron deficiency, due to gastric iron loss ${ }^{19}$. However, in the current study, HP positivity was not found to be more frequent in patients with RLS/WED.

In a study by Rezvani et al. ${ }^{19}$, it was found that serum IgA and IgG antibody positivity for HP was higher in patients with RLS/WED than in the normal population. As a result of that study, it was emphasized that serological screening of HP infection and keeping HP eradication in mind in medical treatment-resistant RLS/WED cases may be important. Currently, used evaluations of biopsy material to show HP infection are highly sensitive. However, there is no similar study in literature where HP has been determined with this method in patients diagnosed with RLS/WED.

Although the appearance of the gastric mucosa in endoscopic follow-up may assist clinical follow-up, confirmation of this appearance by pathological evaluation significantly increases the success of both diagnosis and treatment. In the present study, gastric and duodenal ulcer appearance, the presence of GERD, and Barrett's esophagus appearance were evaluated during upper GIS endoscopy and HP positivity, and inflammatory findings were evaluated pathologically. As a result, no significant difference was found between the RLS/WED and control groups in terms of endoscopic gastric ulcer, duodenal ulcer, GERD findings, and HP positivity.

Several studies demonstrated the role of HP in iron deficiency anemia, which is resistant to oral iron replacement therapy $^{20}$. The most likely cause of this type of anemia is the role of HP in reducing oral absorption of iron ${ }^{21,22}$. Furthermore, given the relation between HP and Parkinson's disease ${ }^{23}$, the possible effect of this infection on dopaminergic pathways may also play a role in the pathogenesis of RLS/WED, which requires further evaluation.

In a study on HP infection in fibromyalgia patients by Olama et al. $^{24}$, the prevalence of RLS/WED in HP-positive patients was $33.8 \%$ versus $9.4 \%$ when compared to HP-negative patients. In a retrospective study by Sun et al. with patients with RLS/WED, a ferritin level $<50 \mathrm{mcg} / \mathrm{L}$ was found to be associated to increased RLS/WED symptoms and the development of sleep disorders ${ }^{25}$. There are not enough studies showing this situation in adult patient groups. In the current study, in parallel to such information, disease severity had a positive correlation with histological inflammation and a negative correlation with serum ferritin level in patients with RLS/WED.

In a study by Appak et al. ${ }^{14}$, chronic gastritis was associated to significant decreases in the sleep and quality of life scores in children.

Celiac disease is another GIS disease that shows an association with RLS/WED. Iron deficiency anemia and excessive bacterial reproduction are thought to be responsible for RLS/WED development in celiac patients ${ }^{11,25,26}$. When the gastric biopsy specimens from the participants in the present study were evaluated in terms of celiac disease, two patients with RLS/WED had histopathologically compatible findings, and none was detected in the control group. Although it was not considered to be clinically significant to observe this condition in such a small number of RLS/WED patients, follow-up of celiac disease detected on early endoscopy could be effective in preventing the development of RLS/WED and regressing the severity of RLS/WED.

The present study has some expressive limitations. Due to the cross-sectional nature of the study, there were difficulties in evaluating the endoscopic indications of patients and the effects of post-endoscopy treatments on RLS/WED symptoms and disease healing. However, the study is thought to

Table 4. Multiple logistic regression of RLS/WED and control patients' results.

\begin{tabular}{|c|c|c|c|c|c|c|}
\hline & \multirow{2}{*}{ B } & \multirow{2}{*}{ S.E. } & \multirow{2}{*}{$p$-value } & \multirow{2}{*}{ Odds Ratio } & \multicolumn{2}{|c|}{$95 \% \mathrm{Cl}$ for Odds Ratio } \\
\hline & & & & & Lower bound & Upper bound \\
\hline Severity of intestinal metaplasia & 0.394 & 0.574 & 0.492 & 1.483 & 0.482 & 4.563 \\
\hline Ferritin $(>17.9)$ & -1.721 & 0.357 & $<0.001$ & 5.592 & 2.776 & 11.264 \\
\hline Severity of mucosal atrophy & -0.325 & 0.422 & 0.441 & 1.384 & 0.605 & 3.162 \\
\hline Severity of inflammation & -0.893 & 0.242 & $<0.001$ & 2.443 & 1.520 & 3.926 \\
\hline Constant & 1.962 & 0.746 & 0.009 & 7.112 & & \\
\hline
\end{tabular}

Dependent Variable: type; Predicted rls: 76.4; Predicted control 64.8; Predicted: 70.6; p<0.001; Multiple Logistic Regression; 95\%Cl: 95\% confidence interval; B: regression coefficients; SE: standard error. 
have a significant advantage over similar studies as to the pathological evaluation of gastric biopsies of patients with RLS/WED, thereby revealing HP.

In conclusion, the severity of intestinal metaplasia, mucosal atrophy, and gastric inflammation was found to be higher in patients with RLS/WED with dyspeptic complaints, whereas ferritin levels were lower than expected. The presence of HP in gastric biopsies was found at a similar frequency in patients with RLS/WED and patients in the control group. There is a need for further, larger randomized and controlled trials on this subject, in which patients are evaluated with an upper GIS endoscopic biopsy.

\section{References}

1. Allen RP, Picchietti DL, Garcia-Borreguero D, Ondo WG, Walters AS, Winkelman JW, et al. Restless legs syndrome/Willis-Ekbom disease diagnostic criteria: updated International Restless Legs Syndrome Study Group (IRLSSG) consensus criteria--history, rationale, description, and significance. Sleep Med. 2014 Aug;15(8):860-73. https://doi.org/10.1016/j.sleep.2014.03.025

2. Allen RP, Picchietti D, Hening WA, Trenkwalder C, Walters AS, Montplaisi J. Restless legs syndrome: diagnostic criteria, special considerations, and epidemiology. A report from the restless legs syndrome diagnosis and epidemiology workshop at the National Institutes of Health. Sleep Med. 2003 Mar;4(2):101-19. https://doi. org/10.1016/s1389-9457(03)00010-8

3. Rye DB, Trotti LM. Restless legs syndrome and periodic leg movements of sleep. Neurol Clin. 2012 Nov;30(4):1137-66. https://doi. org/10.1016/j.ncl.2012.08.004

4. Trenkwalder C, Winkelmann J, Inoue Y, Paulus W. Restless legs syndrome-current therapies and management of augmentation. Nat Rev Neurol. 2015 Jul;11(8):434-45. https://doi.org/10.1038/ nrneurol.2015.122

5. Nagandla K, De S. Restless legs syndrome: pathophysiology and modern management. Postgrad Med J. 2013;89(1053):402-10. https://doi.org/10.1136/postgradmedj-2012-131634

6. Garcia-Borreguero D, Williams A-M. An update on restless legs syndrome (Willis-Ekbom disease): clinical features, pathogenesis and treatment. Curr Opin Neurol. 2014 Aug;27(4):493-501. https://doi. org/10.1097/WCO.0000000000000117

7. Trenkwalder C, Högl B, Winkelmann J. Recent advances in the diagnosis, genetics and treatment of restless legs syndrome. J Neurol. 2009 Apr;256(4):539-53. https://doi.org/10.1007/s00415-009-0134-9

8. Hening WA, Allen RP, Washburn M, Lesage SR, Earley CJ. The four diagnostic criteria for Restless Legs Syndrome are unable to exclude confounding conditions ("mimics"). Sleep Med. 2009 Oct;10(9):97681. https://doi.org/10.1016/j.sleep.2008.09.015

9. Weinstock LB, Walters AS. Restless legs syndrome is associated with irritable bowel syndrome and small intestinal bacterial overgrowth. Sleep Med. 2011 Jun;12(6):610-3. https://doi.org/10.1016/j.sleep.2011.03.007

10. Borji R, Fereshtehnejad SM, Taba Taba Vakili S, Daryani NE, Ajdarkosh $\mathrm{H}$. Association between irritable bowel syndrome and restless legs syndrome: a comparative study with control group. J Neurogastroenterol Motil. 2012 Oct;18(4):426-33. https://doi. org/10.5056/jnm.2012.18.4.426

11. Weinstock LB, Walters AS, Mullin GE, Duntley SP. Celiac disease is associated with restless legs syndrome. Dig Dis Sci. 2010 Jun;55(6):1667-73. https://doi.org/10.1007/s10620-009-0943-9

12. Weinstock LB, Bosworth BP, Scherl EJ, Li E, Iroku U, Munsell MA, et al. Crohn's disease is associated with restless legs syndrome. Inflamm Bowel Dis. 2010 Feb;16(2):275-9. https://doi.org/10.1002/ibd.20992

13. Franco RA, Ashwathnarayan R, Deshpandee A, Knox J, Daniel J, Eastwood D, et al. The high prevalence of restless legs syndrome symptoms in liver disease in an academic-based hepatology practice. J Clin Sleep Med. 2008;4(1):45-9.

14. Appak YCุ, Özyurt G, Karakoyun M, Baran M. Effects of chronic gastritis on sleep and quality of life in adolescents. J Pediatr Res. 2019;6(4):259-65. https://doi.org/10.4274/jpr.galenos.2019.60134

15. Weinstock LB, Walters AS, Paueksakon P. Restless legs syndrome - Theoretical roles of inflammatory and immune mechanisms. Sleep Med Rev. 2012 Aug;16(4):341-54. https://doi.org/10.1016/j. smrv.2011.09.003

16. Ford AC, Gurusamy KS, Delaney B, Forman D, Moayyedi P. Eradication therapy for peptic ulcer disease in Helicobacter pylori-positive people. Cochrane database Syst Rev. 2016 Apr;4:CD003840. https:// doi.org/10.1002/14651858.CD003840.pub5

17. Chan SM, Wu JCY, Teoh AYB, et al. Comparison of early outcomes and quality of life after laparoscopic Heller's cardiomyotomy to peroral endoscopic myotomy for treatment of achalasia. Dig Endosc. 2016 Jan;28(1):27-32. https://doi.org/10.1111/den.12507

18. Yamanishi S, lizumi T, Watanabe E, Shimizu M, Kamiya S, Nagata K, et al. Implications for induction of autoimmunity via activation of B-1 cells by Helicobacter pylori urease. Infect Immun. 2006;74(1):248-56. https://doi.org/10.1128/IAl.74.1.248-256.2006

19. Rezvani F, Sayadnasiri M, Rezaei O. Restless legs syndrome in patients infected with Helicobacter pylori. Neurol Res. 2018 Apr;40(7):583-7. https://doi.org/10.1080/01616412.2018.1454704

20. Konno M, Muraoka S, Takahashi M, Imai T. Iron-deficiency anemia associated with Helicobacter pylori gastritis. J Pediatr Gastroenterol Nutr. 2000 Jul;31(1):52-6. https://doi.org/10.1097/00005176200007000-00012

21. Ciacci C, Sabbatini F, Cavallaro R, et al. 17 P Helicobacter pylori impairs iron absorption in infected individuals. Dig Liver Dis. 2004 Jul;36:455-60. https://doi.org/10.1016/j.dld.2004.02.008

22. Annibale B, Capurso G, Lahner E, Castiglione F, Di Bella S, lovino P, et al. Concomitant alterations in intragastric $\mathrm{pH}$ and ascorbic acid concentration in patients with Helicobacter pylori gastritis and associated iron deficiency anaemia. Gut. 2003 Apr;52(4):496-501. https://doi.org/10.1136/gut.52.4.496

23. Çamcı G, Oğuz S. Association between Parkinson's Disease and Helicobacter Pylori. J Clin Neurol. 2016;12(2):147-50. https://doi. org/10.3988/jcn.2016.12.2.147

24. Olama SM, El-Arman M. Helicobacter pylori in Egyptian patients with fibromyalgia syndrome. Egypt Rheumatol. 2013 Jul;35(3):167-73. https://doi.org/10.1016/j.ejr.2013.01.004

25. Dukowicz AC, Lacy BE, Levine GM. Small intestinal bacterial overgrowth: a comprehensive review. Gastroenterol Hepatol (NY). 2007 Feb;3(2):112-22.

26. Manchanda S, Davies CR, Picchietti D. Celiac disease as a possible cause for low serum ferritin in patients with restless legs syndrome. Sleep Med. 2009 Aug;10(7):763-65. https://doi.org/10.1016/j. sleep.2008.07.01 